\title{
Urdimento
}

Revista de Estudos em Artes Cênicas

E-ISSN: 2358.6958

\section{Outras narrativas sobre estupro: A performance autobiográfica como forma de subversão}

Camila Prado

Nina Caetano

\section{Para citar este artigo:}

PRADO, Camila; CAETANO Nina. Outras narrativas sobre estupro: A performance autobiográfica como forma de subversão. Urdimento, Florianópolis, v. 1, n. 40, mar./abr. 2021.

do) DOI: http:/dx.doi.org/10.5965/1414573101402021e0107

Este artigo passou pelo Plagiarism Detection Software | iThenticate 
Outras narrativas sobre estupro:

A performance autobiográfica como forma de subversão

Camila Prado ${ }^{1}$

Nina Caetano ${ }^{2}$

\title{
Resumo
}

Este artigo parte da experiência traumática do estupro e suas implicações em nível pessoal e social. A fim de investigar as possibilidades de intervenção na esfera pública por meio do teatro performativo, o estudo teve como base a abordagem autobiográfica, analisando trabalhos artísticos realizados sobre o tema. Partindo de uma perspectiva filosófica, foram investigadas estruturas de poder que mantêm a violência sexual, considerando também a subversão que pode emergir de suas brechas. Pensando no senso comum que rodeia o tema, a pesquisa teve como objetivo propor contra-narrativas que desencadeassem processos curativos por meio da atmosfera de denúncia recorrente na cena contemporânea.

Palavras-chave: Estupro. Teatro performativo. Performance autobiográfica.

\section{Other narratives about rape:}

The autobiographic performance as a form of subversion

\begin{abstract}
This article comes from the experience of a rape trauma and its implications in a personal e social way. In order to investigate the possibilities of intervention in the public sphere by the performative theater, the study was based in an autobiographic approach, analyzing artistic works performed about the theme. Through a philosophical approach, the power structures that maintain the sexual violence were investigated, also considering the subversion that might emerge from its gaps. Thinking of the common sense that circles the theme, the research had as a purpose the proposition of counter-narratives that would trigger off healing processes through the denouncement atmosphere, recurrent in the contemporary scene.
\end{abstract}

Keywords: Rape. Performative theater. Autobiographic performance.

${ }^{1}$ Atriz, performer e bacharelanda em Artes Cênicas pela Universidade Federal de Ouro Preto. camilasilvaprado@outlook.com

(9) http://lattes.cnpq.br/7372163052149875 iD https://orcid.org/0000-0002-9800-2893

2 Graduação em Língua e Literatura Francesas pela Universidade Federal de Minas Gerais (1996), na qual também fez seu mestrado em Estudos Linguísticos (2000). É Doutora em Artes Cênicas pela Escola de Comunicações e Artes da USP e Professora Adjunta do Departamento de Artes e do Mestrado em Artes Cênicas da Universidade Federal de Ouro Preto. No PPGAC - IFAC/UFOP atua na Linha de Pesquisa Processos e Poéticas da Cena Contemporânea desenvolvendo a pesquisa Escritas performadas: a escritura do corpo no corpo da cidade. caetano.nina@gmail.com

(6) http://lattes.cnpq.br/4396977006055773 (iD http://orcid.org/0000-0001-6161-5592 
Otras narrativas sobre la violación:

La performance autobiográfica como una forma de subversión

\section{Resumen}

Este artículo parte de la experiencia traumática de la violación y sus implicaciones a nivel personal y social. Con el fin de investigar las posibilidades de intervención en la esfera pública a través del teatro performativo, el estudio se basó en el enfoque autobiográfico, analizando el trabajo artístico realizado sobre el tema. A través de una perspectiva filosófica, investigó las estructuras de poder que mantienen la violencia sexual, considerando también la subversión que puede surgir de sus brechas. Pensando en el sentido común que rodea al tema, el objetivo de la investigación fue proponer contrarelatos que desencadenaran procesos de curación a través de la atmosfera de denuncia recurrente en la escena contemporánea.

Palabras clave: Violación. Teatro performativo. Performance autobiográfica. 


\section{Urdimento}

Este artigo integra o Trabalho de Conclusão de Curso do Bacharelado em Artes Cênicas da Universidade Federal de Ouro Preto, realizado por mim sob a orientação e colaboração da prof. a Dra. Nina Caetano. Nele, nos debruçamos sobre criações artísticas que tiveram como mote a experiência traumática do estupro, para pensá-las não somente no âmbito da cena contemporânea, mas também em suas implicações com a vida. Sobretudo partindo do silêncio social acerca do tema, pretendemos propor uma reflexão sobre as narrativas e representações, muitas vezes estereotipadas, que estão presentes nas diversas linguagens artísticas, para pensar a produção de possíveis contra-narrativas sobre o estupro que possam se constituir como processos, senão de superação do trauma, ao menos como possibilidade de cura.

Nele, pretendemos revisitar e analisar dois trabalhos: a cena A olhos nus não se vê o pêndulo (2017-2019) e o espetáculo Panaceia (2019). O primeiro surge e é desenvolvido a partir do silêncio ao qual fui submetida depois de ter sofrido a violência, evidenciando suas afetações em meu corpo. Já o segundo, além de ser fruto de uma criação coletiva, partiu de relatos pessoais de violência que ganharam forma em cena através da palavra e seus tantos recursos. Ambos os processos se deram sob um viés autobiográfico. A partir deles, vamos discorrer sobre o caráter subversivo que pode estar presente nas estruturas performativas, no testemunho em cena e em outros procedimentos utilizados nas criações artísticas em questão.

As inquietações que originaram a pesquisa nascem, principalmente, do silêncio e dos demais sintomas que podem acompanhar sobreviventes de um estupro, bem como do desejo de tirar o assunto da zona do interdito, do tabu e do indizível, numa tentativa de evidenciar sua recorrência nas diferentes vivências de mulheres trans, mulheres cis e homens trans. Para tal, é indispensável olhar para as condições sociais, políticas e culturais que envolvem a violência e para os modos como suas representações, produzidas pelo senso comum e circulando em variados meios, reforçam e ajudam a sustentar um sistema violento de omissão.

Para traçar um contraponto e uma possível subversão das narrativas comuns de fetichização e dramatização, parto da minha própria experiência a fim de 
explicitar as conexões e os desdobramentos que nela tiveram origem. É importante ressaltar que o lugar de onde falo - meu corpo - é enformado pelas especificidades que me constituem enquanto mulher branca, cis e lésbica, pois tais marcadores sociais incidem sobre minha vivência e limitam meu olhar que, desse modo, não se pretende totalizante nem universal, mas antes dotado de singularidades.

Após ter vivenciado a experiência de um trauma - a do estupro - me debrucei sobre a necessidade de buscar formas de romper com o peso do silêncio que me sufocava (Lorde, 2019, p. 55). O silêncio foi o que mais me gerou angústia no árduo caminho pós estupro, pois sentia uma solidão que, de fato, não é real, já que ocorrem 180 estupros por dia no Brasil $^{3}$, sendo que, em 81,8\% dos casos, são cometidos contra mulheres ${ }^{4}$. Mas então onde estavam essas mulheres? Provavelmente em silêncio também. Embora estivesse visivelmente fragilizada, quando alguém me perguntava se estava tudo bem era impossível responder: "na verdade não, é que fui estuprada na quinta-feira". Falar de estupro não é como contar sobre ser assaltada ou algo do tipo. Relatar um abuso sexual a alguém na maioria das vezes é causar um constrangimento enorme. E esse constrangimento gera silêncio. Então tinha uma ânsia muito grande por evidenciar que o assunto pertence ao cotidiano - já que é onde ele se concretiza: 76,4\% das mulheres que foram estupradas em 2018 conheciam seus agressores ${ }^{5}$ - e sobretudo mudar a

\footnotetext{
${ }^{3}$ Esse número corresponde às notificações registradas na polícia ou no SUS. Considerando as subnotificações, a estimativa média cresce. Segundo a Pesquisa Nacional de Vitimização (Secretaria Nacional de Segurança Pública/Ministério da Justiça, 2013) apenas 7,5\% dos casos são notificados à polícia. Fonte: Anuário Brasileiro de Segurança Pública 2019.

${ }^{4}$ As fontes utilizadas não deixam claro se os dados se referem apenas às mulheres cis ou se abrangem também mulheres trans. No entanto, deixam margem para o entendimento de que dizem respeito majoritariamente a mulheres cis. Gostaríamos de destacar que, quando se trata de violência contra a população transgênera, há uma lacuna nesta pesquisa. Se existe uma enorme cadeia de invisibilização do estupro de mulheres cis, o estupro de pessoas trans não é sequer considerado nos dados oficiais, embora elas possam sofrer violências sexuais específicas em função de sua identidade de gênero (Jesus, 2012), como é o caso de homens trans e trans masculinos que, vistos preconceituosamente como corpos feminizados, são muitas vezes submetidos a uma violência historicamente destinada às mulheres trans e/ou lésbicas: o estupro corretivo. Como uma limitação deste estudo, não se realizou uma análise mais profunda do contexto de violência sexual contra pessoas trans, não havendo condições de que as experiências deste texto deem conta do processo de marginalização dos corpos trans e à recorrente privação de seus direitos básicos. No entanto, torna-se essencial reafirmar que a violência sexual contra pessoas trans ocorre, especialmente em situações de encarceramento e que futuras pesquisas cênicas, sobretudo conduzidas por pessoas trans, podem abranger este campo.
}

5 Dados da pesquisa Visível e Invisível: a Vitimização de Mulheres no Brasil, do Fórum Brasileiro de Segurança 
narrativa que transita no imaginário social e, consequentemente, é apresentada nas formas representacionais - que é geralmente a de extrema dramatização. A respeito disso, Virginie Despentes fala sobre Camille Paglia e sua "liberdade incrível de desdramatização":

Era possível pela primeira vez pensar o estupro de um jeito novo. Esse assunto que até então tinha sido um tabu temível a ponto de não nos permitirmos dizer outra coisa além de "que horror" e "coitadas". Pela primeira vez alguém valorizava a capacidade de se recuperar, mais do que simplesmente recitar uma antologia complacente de traumas [...] isso não anulava nada do que havia acontecido, não apagava nada do que havíamos aprendido naquela noite [de seu estupro]. [...]. Ela foi a primeira a tirar o estupro do horror absoluto, do não dito, disso que sobretudo não deveria jamais acontecer. Ela fez do estupro uma circunstância política, algo que deveríamos aprender a encarar (Despentes, 2006, p.35-36).

Além do desejo de reforçar que o tema pertence a um lugar cotidiano, quis trazê-lo através de uma narrativa diferente da narrativa de horror, que é comum nas várias linguagens - audiovisual, teatro, literatura, artes plásticas - e é, também, a escolha recorrente de sobreviventes que, talvez por falta de outras referências e pela relação íntima de dor com o trauma, encontram algum tipo de conforto nesse lugar, que também é válido, mas pode reafirmar o estigma de que, a sobreviventes, só resta sofrer, sem outra possibilidade de (re)ação.

Um exemplo interessante de contra-narrativa dentro da linguagem audiovisual é o filme argentino Paulina (2016), de Santiago Mitre, que aborda o estupro como um problema social antes de tudo. Para começar, um aspecto interessante é a escolha por não colocar uma cena de estupro no roteiro, recurso praticamente unânime entre cineastas, ao abordar o tema - e geralmente o fazem de uma forma fetichizada e obsessivamente focada na reprodução estética da violência, como Gaspar Noé que, em Irreversível (2002), realiza uma cena de estupro com cerca de quinze minutos de duração. Santiago Mitre, ainda que com seu olhar evidentemente cis-masculino, não deixa de lado a forma com que a violência afeta Paulina em nível pessoal, tratando-a de maneira sensível. A obra suscita um dilema ético e moral, já que a personagem - advogada e professora

Pública (2019), ainda demonstram que estupros são cometidos, em geral, por homens cis. 
em uma área pobre da Argentina - decide não denunciar seus agressores, que são seus próprios alunos, por acreditar que a justiça procura culpados e não a verdade. E geralmente os sujeitos passíveis de condenação têm pele preta e/ou pertencem a uma classe mais baixa. Isso evidencia que importam menos as vítimas, no final das contas, pois a prioridade é punir pessoas marginalizadas e proteger os homens que ocupam o topo dos privilégios - brancos, cisgêneros e ricos. Um problema do sistema judiciário e do racismo estrutural que se arrasta, em território americano, desde a colonização.

Em seu livro Mulheres, Raça e Classe (2016), Angela Davis trata do mito do estuprador negro, muito recorrente nos séculos XIX e XX, mas que segue atrelado ao inconsciente coletivo até hoje, ganhando diferentes formas de vazão. Ela fala de como as escritoras pioneiras do movimento antiestupro - mulheres cis brancas - ajudaram a disseminar essa ideia, fazendo associações absurdas da escravatura ao suposto desejo de vingança do homem negro que, segundo elas, encontraria na mulher branca essa possibilidade, contribuindo para a institucionalização de uma cultura de linchamento de homens negros. Neste sentido, o estupro estaria colocado como estratégia de terror da supremacia branca, a fim de manter o controle sobre homens e mulheres negros após a abolição da escravidão. O estupro, que é uma violência tão antiga quanto a guerra, surge, no contexto discutido por Davis, como arma do desejo genocida e territorialista, sendo, em sua essência, estratégia colonizadora, seja do corpo, do território ou de determinada cultura. Desse modo, ele está intrinsecamente ligado a um projeto político e histórico de poder. Portanto, para entender seu funcionamento e suas consequências na vida das mulheres americanas ${ }^{6}$ - entendendo também quais são, dentre elas, as mais vulneráveis - é necessário se ater à lógica colonialista, racista e punitivista que o sustenta, de maneira a proteger determinados grupos e garantir a manutenção de seus privilégios e do domínio sobre os corpos marginalizados.

${ }^{6} \mathrm{E}$ aqui nos referimos tanto às mulheres latino-americanas quanto àquelas que habitam os Estados Unidos e o Canadá. 
Segundo Flávia Bello Costa de Sousa7, depois de um episódio de estupro, além do silêncio, muitas vítimas relatam o desejo da invisibilidade e a sensação de estagnação, apatia, dissociação, dentre outros sintomas que podem fazer parte do TEPT (Transtorno de Estresse Pós-Traumático). Um número considerável de sobreviventes desenvolve transtornos psicológicos depois da violência. Foi neste contexto que, em 2017, iniciei a primeira investigação sobre o tema, na disciplina de Expressão Corporal IV, ministrada pelo professor Éden Peretta ${ }^{8}$ a partir do trabalho sobre as "cinco peles", que dizem respeito às dimensões e relações que transcendem a matéria do corpo. Um corpo “multi-epidérmico", que vai além da organicidade material e é composto por suas marcas, vestimentas, entorno, relações sociais e tudo mais que o constitui.

A intenção era explorar de outras formas o silêncio, motivo de meu incômodo latente. No decorrer das experimentações de minhas camadas epidérmicas, iam surgindo adjetivos, termos, elementos e sensações que orientaram o trabalho: apatia, inércia, solidão, sufocamento, invasão. Além disso, surgiram também materialidades bastante significativas: um vestido vermelho, um grande tecido da mesma cor, cigarros e suas cinzas. A partir desses recursos, fui experimentando uma corporeidade tomada pela paralisia, mas, ao mesmo tempo, com uma pulsão monstruosa dentro de si; um silêncio inquietante; um vazio preenchido de incômodos. Foi nessa relação de recorrentes antíteses que pude pesquisar a nãoforma, o vazio, o silêncio, a estagnação e a desumanização de um corpo violentado.

Cassiano Sydow Quilici, em seu livro O ator-performer e as poéticas da transformação de si (2015), fala da recusa, que se tem observado na cena contemporânea, de um fazer teatral que parta de um processo de ficcionalização e da construção de um mundo imaginário, trazendo a obra de Antonin Artaud e Marina Abramovic - embora pertençam a momentos diferentes - como exemplos

\footnotetext{
${ }^{7}$ Dados de sua dissertação de mestrado intitulada Consequências emocionais de um episódio de estupro na vida de mulheres adultas. Para a pesquisa, a autora entrevistou 37 mulheres cis, vítimas de estupro que estavam em tratamento no serviço de Saúde Pública do Hospital Pérola Byington, em São Paulo, no ano de 2013. Na dissertação, ela investiga o TEPT, a depressão, alterações na autoestima e demais reações que foram apresentadas pelas mulheres entrevistadas, baseando-se em uma perspectiva da Psicologia.

8 As cinco peles: a investigação de si como matriz dramatúrgica no ensino de dança intitula o artigo do Professor Éden Peretta (DEART/UFOP), que aborda o conceito das "cinco peles", do pintor e arquiteto austríaco Friedensreich Regentag Dunkelbunt Hundertwasser.
} 
do desejo de uma "transformação de si" enquanto método de criação artística. Quilici coloca a ação performática como um dispositivo de comunicação e interferência direta na realidade, que pode transgredir convenções estéticas e sociais e tem potencial transformador no sentido estético, político e existencial. Traz também a prática do riso de si como gesto libertador que pode desencadear uma transformação dos modos de percepção predominantes, criando um tipo de relação potente com o público. Além disso, ele propõe uma relação entre treinamento artístico e a estética da existência, conceito foucaultiano que diz respeito à busca por um modo de vida ético, que parte do cuidado de si.

Sem deixar de problematizar as abordagens superficiais que podem emergir desse conceito - especialmente quando aplicado aos modos de vida contemporâneos do Ocidente - Quilici procura a relação entre as "técnicas de si" e as práticas artísticas, sugerindo uma aproximação entre ambas. No seu entendimento, existe uma familiaridade entre a noção de estética da existência e os exercícios, treinamentos e procedimentos que artistas exercem a fim de obter uma experiência intensa, que possa gerar intervenção no real e no cotidiano. Mas, segundo o autor, tal noção - que Michel Foucault foi buscar na Antiguidade precisa ser aprofundada através de uma constante pesquisa teórico-prática, que talvez tenha sua base e transmissão de conhecimento ainda vivas em outras culturas, como por exemplo, no Oriente.

\begin{abstract}
A intersecção entre o pensamento de Foucault e a reflexão artística é particularmente presente quando se trata de considerar a arte como campo que coloca em jogo as possibilidades de reinvenção do próprio artista, pretendendo assim contaminar ou convidar o público a compartilhar da sua experiência ou, para utilizar uma expressão do autor, a arte vista como um lugar em que se desencadeiam processos de subjetivação (Quilici, 2015, p. 151).
\end{abstract}

Outro aspecto importante, abordado por Quilici, diz respeito às potências da solidão, que coloca como experiência necessária para a construção de um trabalho coletivo. Para alcançar um estágio imersivo de concentração e intensidade, artistas devem trabalhar sobre si, sustentando a própria solidão, a fim de suscitar um estado de atenção e escuta. Esse distanciamento permite a escuta apurada das 
próprias inquietações e outra percepção do tempo, dando espaço para apreender o que está entre uma palavra e outra. O autor introduz também o silêncio como uma linguagem possível para criar a partir de circunstâncias delicadas e atingir determinados estados de atenção. Diante da situação de um trauma, por exemplo, discorre sobre as situações que extrapolam a lógica linear da fala:

Diante da extrema violência - física, sensorial, emocional - o psiquismo não é capaz de representar o que viveu e transformar a vivência através da linguagem. A ausência de alguma forma de representação, neste caso, pode significar o enclausuramento do indivíduo na intensidade das memórias e sensações, que ganham expressões involuntárias no corpo, tais como tiques, sintomas etc. Parece-nos necessária uma linguagem especial para se estabelecer conexão com o intolerável destas situações, uma linguagem que trabalhe justamente com os limites do dizível, e que circunscreva, de algum modo, uma experiência próxima do irrepresentável (Quilici, 2015, p. 112).

Sobre o silêncio que emerge da dificuldade da fala, um "não dizer carregado de sentido" (2015, p. 54), Quilici menciona os fluxos internos, os impulsos, as memórias e a vontade de verdade que um corpo impossibilitado de verbalizar algo carrega. Como ele afirma, um corpo aparentemente inerte, em estado apático, muitas vezes comporta um turbilhão de sensações e memórias que não conseguem sair de maneira facilmente decifrável. Neste sentido, quis, com meu trabalho de pesquisa, explorar as nuances entre um estado de euforia, de pânico e um estado de paralisia. Uma forma sutil e, ao mesmo tempo, densa de abordar os efeitos de uma violência tão invasiva, que desperta uma raiva que move e, ainda assim, deixa a sensação de impotência. Ao contrário da vida cotidiana, em que o silêncio a respeito do estupro pode ser conveniente e cômodo ao sistema que o mantém, em cena ele pode causar o efeito contrário, dependendo da forma como for trabalhado. O silêncio, a dilatação do tempo, o "nada”, um corpo que grita internamente, que se flagela e se exibe, transita entre o erotismo e a morbidez.

Em $A$ olhos nus não se vê o pêndulo, a cena em questão, essa atmosfera descrita é instaurada. Estou sozinha em uma sala preta, usando um vestido vermelho-sangue e segurando a ponta de um tecido da mesma cor com aproximadamente três metros. Apenas a minha silhueta pode ser vista pela 
iluminação em penumbra enquanto as pessoas começam a entrar. O público é disposto em meia lua pelo espaço, ao meu redor.

A ação se inicia quando começo a colocar o tecido na boca, até provocar um engasgo, um sufocamento, me fazendo ceder e puxá-lo. Depois desenvolvo ações impulsionadas pelos verbos enforcar, sufocar, afogar, trabalhando com o tecido de forma a estabelecer um "pêndulo" entre morte e vida, numa ação quase suicida. Envolvo minha cabeça no tecido, fazendo com que ele dê voltas no meu pescoço. Com os pés, vou puxando a ponta do tecido de modo a me enforcar, ao mesmo tempo que tento impedir a ação. Deitada no chão, após alcançado um estado de esgotamento, eu retiro, enfim, o tecido da cabeça e o vestido vermelho, como se, numa espécie de autoflagelo, esse desnudamento estivesse sendo feito por outras mãos, tal qual o sufocamento. As luzes se apagam, enquanto estou deitada numa posição que alude à obra A Origem do Mundo (1866), de Gustave Courbet. Depois, entre feixes de luz, reproduzo corporalmente esculturas de Camille Claudel, como num convite à contemplação quase erótica de um corpo exausto, violentado, automatizado. Entre o apagar e acender de refletores, o último blackout. Estou encostada no canto esquerdo da sala, deitada, iluminada por uma luz baixa. Seis cigarros queimam na minha boca até apagar, o que leva aproximadamente doze minutos, enquanto permaneço imóvel. A porta é aberta. A partir daí, o público escolhe se fica ou se vai, e quando vai. Fico até que a última pessoa saia.

O pêndulo que dá nome à cena diz respeito a essa característica ambígua: ao mesmo tempo em que busco ações como o enforcamento, sou eu quem o impeço. É um corpo que está no limiar entre a apatia e a euforia. Com o último momento da cena, em que não há roteiro pré-definido, a não ser a ação de deixar queimar os cigarros na boca, quis propor um corpo inerte e ainda em movimento, inalando a fumaça, sendo queimado com as cinzas, sofrendo as afetações. Nessa parte final, há uma maior vulnerabilidade aos acontecimentos, já que o público é levado a decidir se permanece "comigo" ou se vai embora.

Nas duas ocasiões em que apresentei a cena - ambas no Departamento de Artes Cênicas da Universidade Federal de Ouro Preto, em 2017 e 2019, respectivamente - quando a porta foi aberta, poucas pessoas saíram de imediato. 
Talvez entre as que escolheram permanecer, algumas estivessem esperando por um desfecho ou que algo mais acontecesse, e outras ficaram para continuar testando junto comigo meus limites, para ver até quando aguentaria ficar com os cigarros na boca, em uma espécie de participação que me pareceu um tanto quanto voyeurística. Um colega que assistiu à cena disse que sua dificuldade de ir embora se deu devido à sensação de estar me abandonando. Já outra colega, que também esteve presente, contou ter se sentido numa posição de sadismo por ter ficado e observado passivamente à ação.

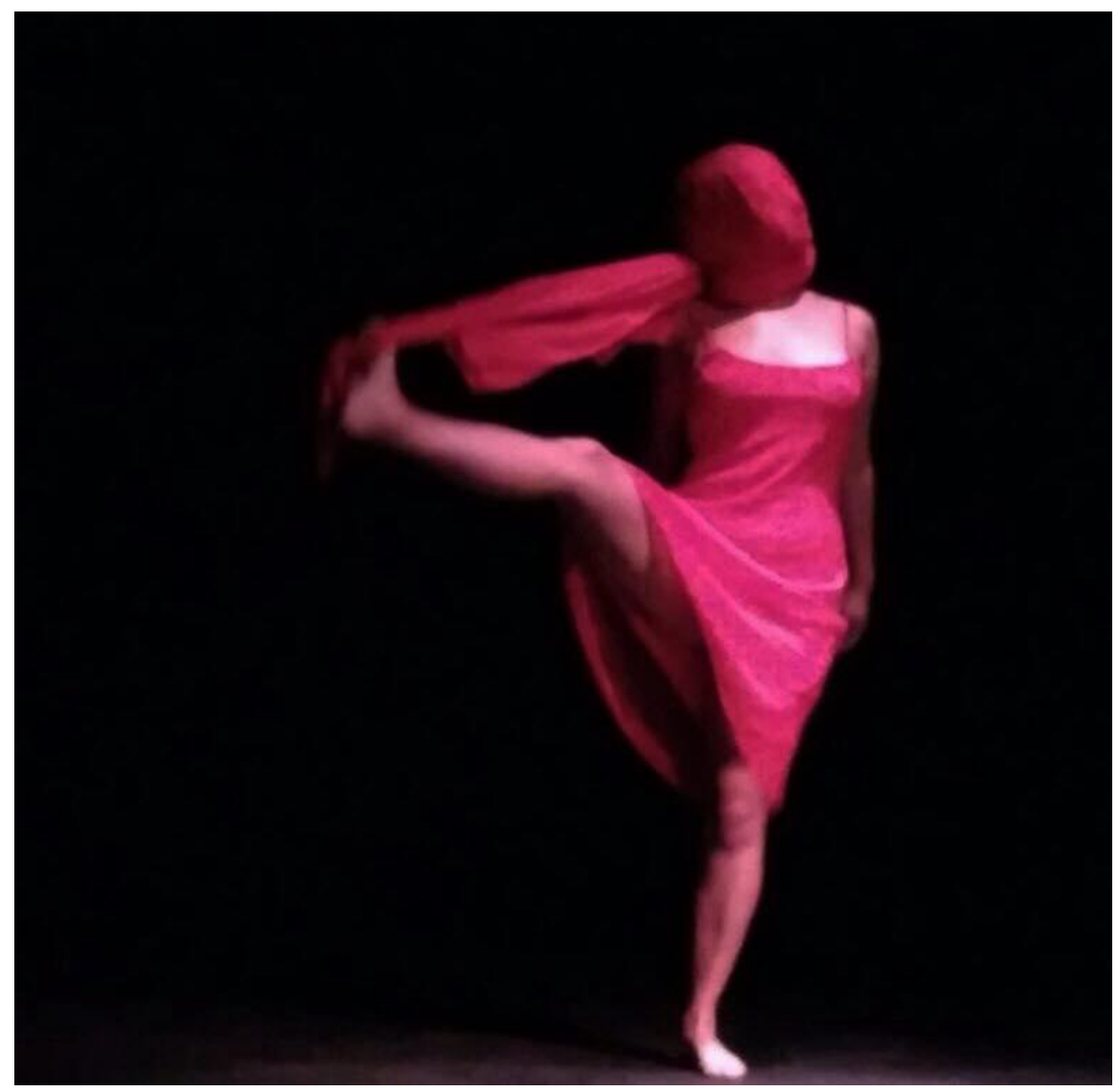

Através da dinâmica de levar meu corpo a um esgotamento e recuar, propondo uma contemplação de sua fragilidade, quis convidar o público a se perceber diante de uma situação violenta e, de certa forma, ter algum tipo de 
decisão ao final da cena: ficar e contemplar um corpo que se degrada ou deixá-lo, sendo que ambas as escolhas poderiam, no meu entendimento, insinuar uma postura passiva, embora não exatamente.

É comum, na performance, a característica de expor o corpo a situações extremas ou levá-lo aos seus limites físicos e mentais. Marina Abramovic é uma artista que exemplifica claramente este aspecto. Segundo Ana Bernstein (2001), a performance solo autobiográfica tem sido fundamental para que mulheres denunciem questões intrinsecamente ligadas aos seus processos de subjetivação, trazendo para o debate questões sociais específicas de uma sociedade misógina e de suas diferentes vivências marcadas por gênero, raça, classe e sexualidade. Talvez a prática de submeter o corpo a seu limite esteja intimamente relacionada às vivências de violência que mulheres carregam, especialmente às que fogem à norma, como é o caso de mulheres pretas, trans e/ou lésbicas. Bernstein fala, ainda, de como a identificação só é possível graças às diferentes identidades e como a ação autobiográfica possibilita um processo de reconhecimento: da experiência da outra, da sua própria e dos diferentes contextos. Neste sentido, a artista se torna uma ponte, não só entre o antes e o agora, mas entre sua própria experiência e a da outra pessoa. Ocupa, com seu corpo, um entrelugar, ao fazer dele um depoimento vivo, compartilhado através da própria presença.

Depois de ter explorado a linguagem do silêncio por meio de meu corpo e da experiência solo, quis tomar o caminho contrário e buscar, na linguagem verbal, uma forma de preencher as lacunas deixadas por uma forma violenta de silenciamento social. Foi junto ao Coletivo Ébria - um encontro de mulheres cis que desejavam explorar suas questões mais pungentes e pulsantes pelas vias do teatro e da performance - que pude experimentar não apenas uma linguagem diferente, mas também a troca por meio da palavra. Essa e outras propostas deram origem ao espetáculo Panaceia (2019), dirigido por Juliana Pamplona?.

O espetáculo propunha um trânsito entre real e ficcional, encontrando em

9 Juliana Pamplona é doutora em Artes Cênicas, dramaturga, diretora teatral e pesquisadora. Graduada em Teoria do Teatro pela Universidade Federal do Estado do Rio de Janeiro (UNIRIO), realizou seu doutoramento no Programa de Pós-Graduação em Artes Cênicas na UNIRIO. 
sua base histórias colhidas de diversas mulheres cis - de nós mesmas, nossas mães, avós, tias, irmãs, amigas e também daquelas com quem tivemos a oportunidade de conversar nas ações realizadas entre 2017 e 2019 na cidade de Ouro Preto/MG. Essas diversas vivências, que tanto se aproximavam entre si, nos permitiram passar por questões como maternidade, raça, sexualidade, violência, memória, desejo e futuro. A princípio, éramos cinco atrizes num processo de direção coletiva - além de mim, Gláucia Venâncio, Karina Sá, Sheiquellann e Tatiane Andrade, todas estudantes do curso de Artes Cênicas da Universidade Federal de Ouro Preto na época - e nos alternávamos nas propostas de experimentação que se tornariam cenas.

Escolhi tratar, em minha proposta, das violências tabus que carregávamos individualmente. Como mote inicial do processo, pedi para que as atrizes escrevessem um relato sobre violências que tivessem sofrido. A ideia do testemunho como dispositivo de enunciação (Cornago, 2009) tem sido recorrente escolha de artistas para narrar histórias pessoais que também pertencem ao campo do social. Janaína Leite, em sua dissertação Autoescrituras performativas: do diário à cena (2014), aborda os diários como forma de autoescritura para desenvolver um método para a criação dramatúrgica. Ela menciona algumas possibilidades de uso do diário, que pode ser entendido como uma prática, ato ou a própria matéria bruta para a dramaturgia, servindo de narrativa textual, registroimagem, acúmulo de indícios da experiência (acervos, memoriais) e registro de processo. "O depoimento é o caminho para se atingir a expressão de uma espécie de inconsciente coletivo onde a história de cada um passa a ser a história de todos" (Leite, 2014, p. 38).

A partir dessa espécie de autoescritura, propus iniciar a experimentação com o jogo das seis possibilidades, em que as atrizes se deslocavam pelo espaço enquanto respondiam a seis diferentes comandos correspondentes às ações: parar, correr, deitar, cantar uma música, pular e contar um fragmento do relato. Isso nos deu a oportunidade de criar certa familiaridade com os relatos e tirá-los da zona do não dito à qual pertenciam. Tive a ideia de trazer um jogo comum da nossa adolescência, conhecido por "eu nunca”, para evocar um ambiente 
considerado corriqueiro e evitar o lugar comum da narrativa melodramática sobre o trauma.

O jogo se desenrola em torno de afirmações - que podem ser verídicas ou não - de pessoas que compartilham alguma bebida alcóolica no decorrer das rodadas. Por exemplo, alguém diz "eu nunca fui ao Rio de Janeiro" e quem já foi deve beber. Seguimos o roteiro usual do jogo, mas pedi para que, entre uma afirmação e outra, incluíssemos trechos e situações dos relatos. Para dar camadas de significação e dinamicidade ao jogo, além de trazê-lo para o lugar da performatividade, resgatamos ações da dramaturgia inicial a serem exploradas simultaneamente a ele: se arranhar, se masturbar, cantar uma música, observar, dançar, contar uma história de amor, encarar um homem cis do público, contar o relato de violência, contar uma lembrança feliz. A ideia era desvencilhar a cena da noção de obra acabada e deixar espaço para que se adaptasse aos estímulos que surgiam a cada experimentação.

O teatro performativo (Féral, 2015, p. 113) emerge da necessidade de transcender a dimensão meramente representacional/ficcional que vigorava no teatro até meados do século XX, quando estes e outros aspectos começaram a ser questionados. Surgiu uma necessidade de aproximar a cena do real, do cotidiano, provocando um deslocamento da ideia de representação para a de ação. A abertura do teatro à possibilidade da performance trouxe à cena o caráter de evento, do acontecimento no momento presente, que está passível de afetação, propondo espaços de instabilidade e instigando o público a ocupar um lugar ativo, demandando dele uma constante adaptação à fluidez que se instaura com o jogo proposto. Segundo Josette Féral, o jogo "ameaça” a cena teatral, pois transgride suas próprias proibições estabelecidas como regras e rompe com a moldura que o teatro estabelece, dando assim espaço à vida. A partir daí se instaura uma nova atmosfera, ambígua e pertencente ao tempo presente, entregue às possibilidades do aqui e agora.

Nas improvisações feitas durante o processo de criação, compartilhamos histórias de abuso e assédio que nunca tinham aparecido nas nossas tantas conversas. Além de parceiras de cena, somos amigas e, ainda assim, o estigma 
encobria nossas vivências que tanto têm em comum. No espetáculo, estendemos o jogo às mulheres cisgêneras, às mulheres transgêneras e aos homens transgêneros do público. Pretendíamos instaurar no espaço algum tipo de segurança para que se sentissem convidades a compartilhar suas histórias. Ao passo que íamos trazendo à tona nossas narrativas, ecoavam mais relatos de pessoas que compartilhavam experiências comuns às nossas e também outros tipos de violência próprias de suas realidades como, por exemplo, a violência obstétrica.

Cada um dos muitos goles de vinho revelava uma estrutura cruel de omissão da qual fazemos parte. Quando disse "eu nunca fui estuprada", olhei ao redor e eram muitas as pessoas que estavam compartilhando o vinho. A escolha de um jogo que remete à adolescência nos permitiu criar um ambiente descontraído e intimista. Também pensamos que soaria familiar a ideia de estarmos reunidas tomando um vinho e contando causos e, ao mesmo tempo, rompendo com isso ao dizer o execrável de maneira cotidiana e irônica. Lembrávamos das nossas histórias mais afetuosas, muitas vezes cômicas e, em seguida, no mesmo tom, vinha um relato repugnante de violência. Rimos de nós mesmas, da figura do agressor, levamos a situação ao absurdo que de fato é. A ideia era que retomássemos um tema que quase sempre é narrado por homens cis, ou seja, sob a visão do potencial agressor. 


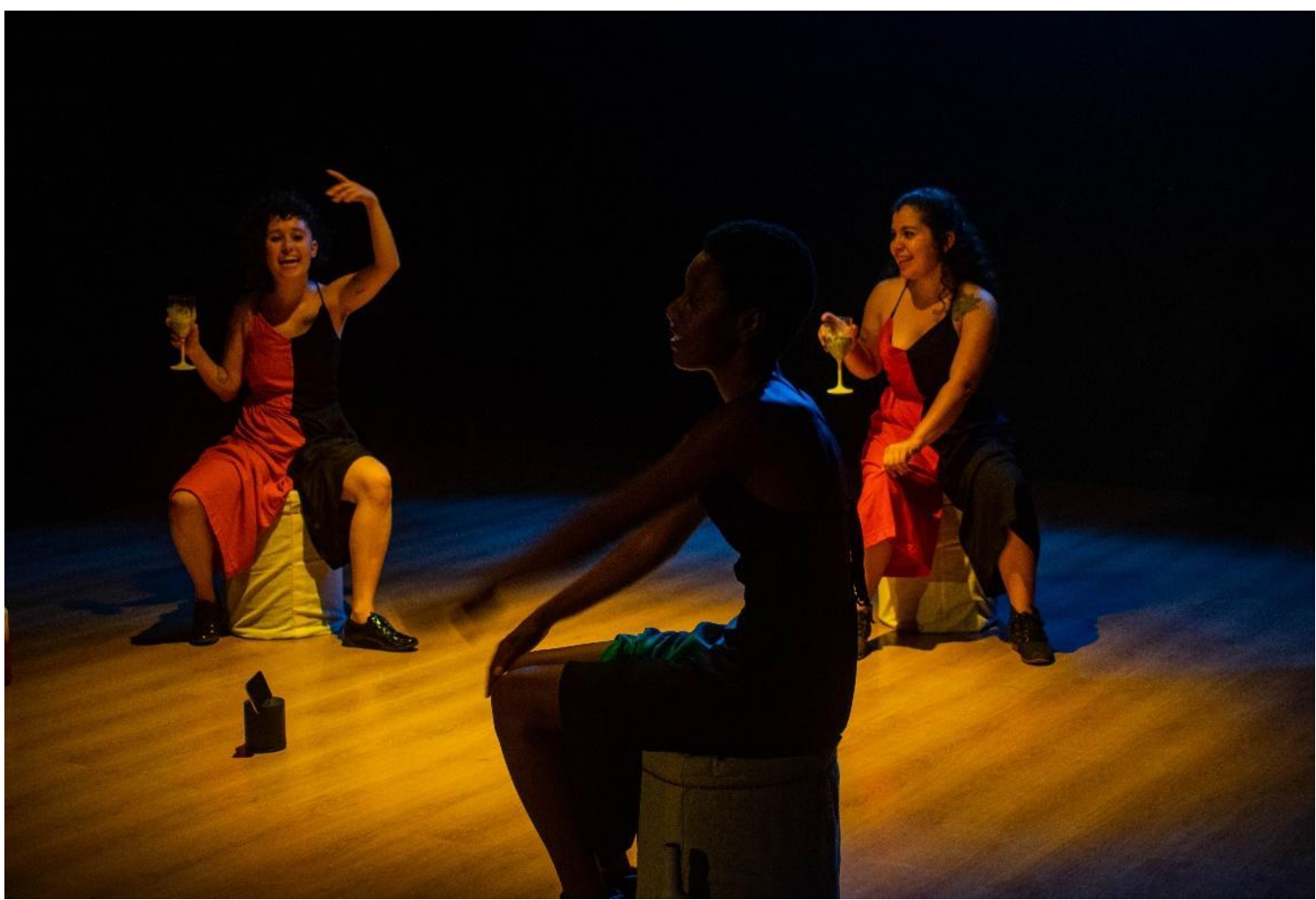

A maneira irônica que utilizávamos para narrar essas histórias "intragáveis" foi escolhida justamente numa tentativa de não permitir ao público, especialmente aos homens cis, um lugar de passividade e para evitar as reações de pena, que muitas vezes estabilizam o público num lugar de conforto ou até de indiferença.

Ao final da cena, depois que narrava minha história de estupro - esta era uma das últimas ações presentes no roteiro performativo que nos guiava - a musicista responsável pela trilha original do espetáculo, Luiza Gaião, que também participava ativamente do jogo, cantava uma música que narra, de maneira muito sensível, o dia 24 de Fevereiro, que é como se intitula a canção e também o dia em que sofri o estupro. Ao mesmo tempo em que o público era convidado a adentrar numa atmosfera de riso, havia momentos como esse, em que o silêncio dominava, fosse pelo teor violento dos relatos ou pela possível empatia que eles suscitavam.

Antes mesmo de acabar a canção, eu e as outras atrizes deixávamos a cena, 
seguidas por Luiza. Não havia espaço para aplausos, resultando em uma espécie de silêncio coletivo e potencialmente incômodo. Acreditamos que os aplausos poderiam causar um efeito catártico que não seria interessante para a cena neste momento, já que romperia o silêncio que fora acentuado. Essas válvulas de escape presentes no jogo possibilitavam um trânsito entre as duas atmosferas - a do riso e a de suspensão - causando reações opostas, como por exemplo, o choro em tensionamento com o riso, seguido novamente de silêncio.

Essa era a cena que encerrava o espetáculo e também o momento em que narrávamos em primeira pessoa nossas próprias histórias, sem traços ou intenção de uma representação teatral, como é tradicionalmente entendida. Neste sentido, a cena não tinha característica de obra fechada, mas de um acontecimento no aqui e agora da ação. Eram nossos depoimentos em estado bruto (Fernandes, 2013, p. 410), corpos-testemunhas que convidavam quem estava ali a revisitar as próprias memórias e, talvez, compartilhá-las.

Mas também corremos riscos com essa escolha, bem como propõe a estrutura performativa. Ao mesmo tempo em que queríamos causar incômodo nos homens cis, havia mulheres e homens trans compartilhando dos nossos traumas e revisitando memórias possivelmente dolorosas e não elaboradas. Não sabíamos como esse grupo de pessoas receberia uma perspectiva tão pouco usual. Logo após a nossa única apresentação, que aconteceu no Departamento de Artes Cênicas da universidade, recebemos mais retornos de homens cis do que de mulheres e de homens trans. As impressões passavam pelos mesmos lugares: alguns disseram sentir nojo de si mesmos e surpresos com a quantidade de relatos, além de terem sido levados a repensar situações problemáticas em que estiveram envolvidos. Outros agradeceram e destacaram a importância da firmeza ao tratar do tema e colocá-los em um lugar desestabilizador e de confronto com a estrutura misógina na qual estão inseridos.

A fim de tomar maior conhecimento das impressões das mulheres espectadoras, criei um formulário anônimo que buscava identificar um pouco de sua experiência e também a forma como se sentiram durante a cena. As respostas foram colhidas entre os dias 28 de setembro e 6 de outubro de 2020. Das dez 
mulheres que responderam à pesquisa, nove se identificaram como cis e uma como trans. 66,7\% tinham entre 21 e 25 anos, 11,1\% entre 18 e 21 anos, 11,1\% entre 25 e 30 anos e 11,1\% tinham mais de 40 anos. 88,9\% afirmaram já ter passado por um episódio de violência sexual. Além disso, todas afirmaram já ter sofrido violência verbal e/ou psicológica e 88,9\% afirmaram já ter sofrido assédio sexual.

Quando questionadas sobre o tom escolhido na abordagem, a maioria disse ter ficado surpresa com a forma com que as histórias foram narradas e uma até mesmo relatou ter sentido dúvida sobre a veracidade dos fatos. No geral, as impressões foram de estranhamento quanto ao tom cotidiano e de "brincadeira", embora essa característica não tenha impedido a abertura de um espaço de diálogo e reconhecimento, de acordo com as participantes da pesquisa. Muitas das respostas mencionaram o ambiente seguro para mulheres, onde foi possível compartilhar histórias parecidas que, embora dolorosas, reafirmaram a força desse encontro que permitiu reconhecer a si mesma nas outras. O contexto do jogo e a música ambiente também foram citados como contribuição para deixar o ambiente mais confortável. Duas mulheres relataram ter sofrido gatilhos ${ }^{10}$, sendo que uma delas disse ter se sentido reconfortada pelo fato de não estar sozinha, apesar da inevitabilidade de revisitar memórias. A maior parte das espectadoras afirmou ter se sentido convidada a participar do jogo, embora não em todos os momentos. Houve um relato de sensação de "anestesia" durante o jogo, devido ao choque diante dos relatos. 55,5\% disseram ter sido a primeira vez que viram uma abordagem do tipo em relação ao tema. Os seguintes trechos são respostas das espectadoras às perguntas: qual sua opinião sobre o tom escolhido para tratar do assunto? Qual impressão te causou?

Acho que a cena tem um potencial de diálogo com o público muito forte, principalmente com as mulheres. É como se a cada fala nos tornássemos mais cúmplices, parceiras, irmãs. Um momento de reconhecimento na outra, um ritual de libertação dos nossos corpos, das nossas vozes. (Espectadora A)

Achei convidativa. Por mim continuaria horas ali papeando, sabe!? Têm pessoas que entraram no jogo dando seus depoimentos...eu entrei

${ }^{10} \mathrm{O}$ termo gatilho se refere a estímulos emocionais que podem ser causados no cérebro por eventos e/ou situações que remetam a memórias, traumas, lembranças. 
também, a fala minha talvez fosse outra: a escuta. E este ouvir foi me colocando naquele espaço ali junto com vocês, me reconhecendo em certos momentos. Acho que cada uma fala da forma que consegue contar e isto pra mim é reconfortante, mesmo que o assunto seja violento. (Espectadora B)

Na época em que assisti a cena fiquei apática, me senti anestesiada, por conta de não querer acessar tais sentimentos, acho que foi uma forma do meu corpo bloquear qualquer afetação que viesse me recordar do ocorrido. Senti que não foi um tom para sensibilizar, mas sim para criar rupturas e quebras com tudo o que há de pior e está normalizado na nossa sociedade. (Espectadora C)

No início me causou estranhamento, pois nunca havia visto mulheres falarem de seus traumas dessa forma. Pareceu meio absurdo acreditar que este tipo de situação pode ser superado a ponto de ir pra uma cena como uma brincadeira leve. Portanto não me pareceu desrespeitoso ou banalização dessas dores, acredito que seja pelo fato de serem mulheres falando de suas vivências. (Espectadora D)

Figura 3 - Espectadoras durante o jogo. Panaceia (2019). Foto: Sabriny Melo

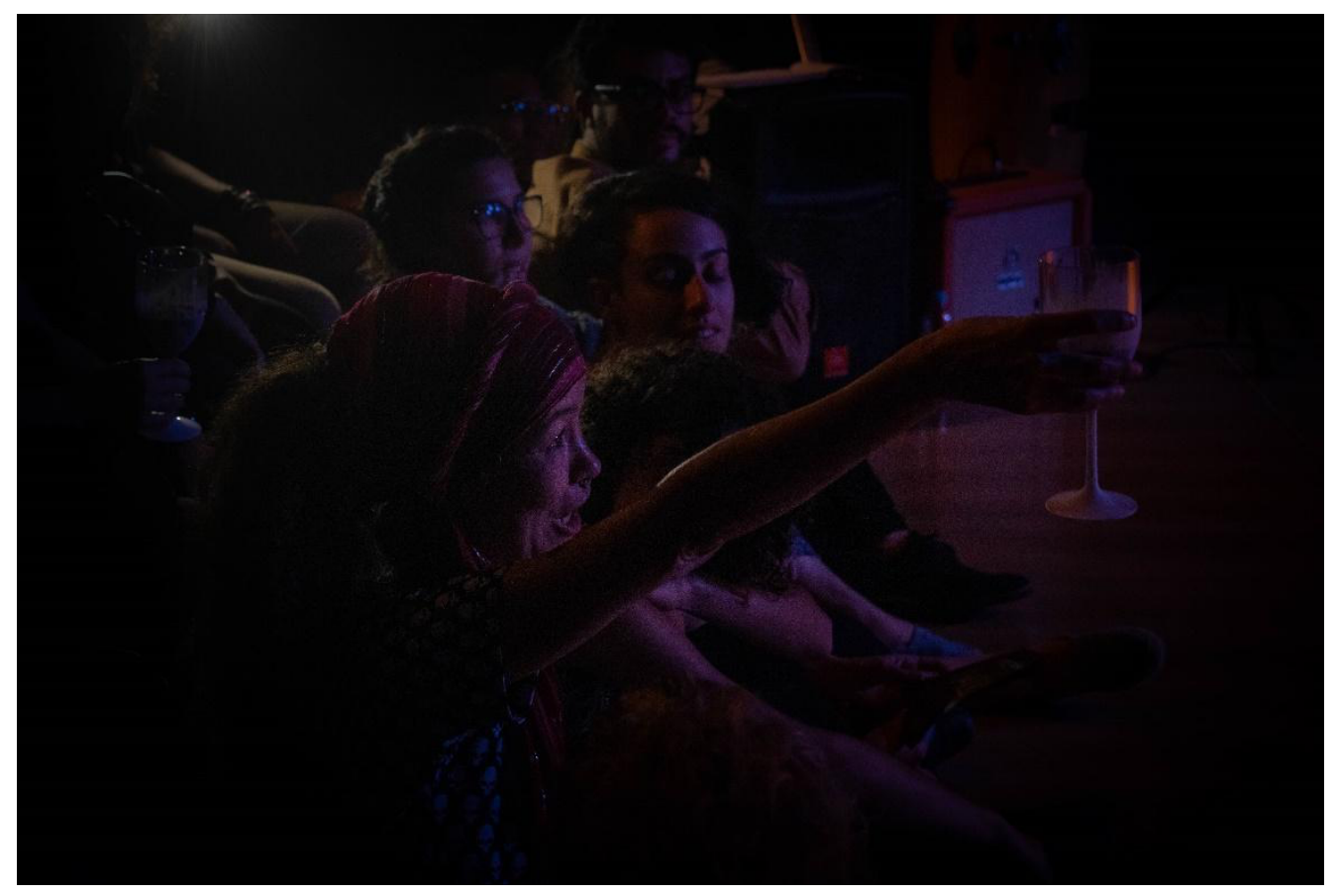

É relevante pensar no que motiva as reações de surpresa diante da possibilidade de o assunto violência sexual ser tratado por meio do riso e em um contexto de "conversa comum", como disse uma das espectadoras, gerando até dúvida. A respeito desse espaço do não-dito, da omissão, Virginie Despentes 
afirma:

Nós nos obstinamos em fazer com que o estupro seja algo de raro e de periférico, algo fora da sexualidade, evitável. Como se dissesse respeito apenas a uns poucos agressores e a umas poucas vítimas como se constituísse uma situação singular que não tivesse nada a ver com a normalidade. (Despentes, 2006, p. 41).

A fim de criar uma ruptura do lugar de silêncio, vi no humor uma força muito grande para escancarar fissuras sociais através da minha própria fragilidade, daquilo que vinha carregando comigo - assim como muitas sobreviventes - e que era um incômodo que eu não deveria carregar sozinha. Como disse anteriormente, com essa escolha corri riscos, já que não se trata de um trauma somente meu. A maioria das mulheres que respondeu ao formulário também já sofreu violência sexual, cada uma com suas memórias, seus contextos, mas embrenhadas numa mesma teia silenciosa de violência que, de alguma forma, precisava ser trazida para o debate.

Independente da abordagem, trazer à tona um assunto tão espinhoso sem dores e incômodos era impossível: estávamos tocando em feridas, coletivas e individuais, que poderiam estar em processo inicial de cicatrização. Mobilizar a memória da outra pessoa através da própria é tarefa delicada, especialmente por se tratar da intenção de se provocar efeitos opostos. A intenção era causar incômodo em determinado público - masculino cisgênero - e proporcionar certo tipo de acolhimento aos corpos feminizados, mas os dois estavam lá, compartilhando o mesmo espaço, ainda que de maneiras diferentes. E essas diferenças se fizeram evidentes com as afetações relatadas por homens cis e por mulheres cis e mulheres trans que estiveram diante dos mesmos corpos, mas foram atravessados e atravessadas de variadas formas.

Óscar Cornago, em seu artigo Atuar "de verdade": a confissão como estratégia cênica (2009), fala da força que tem a presença de um corpo que experimentou, viveu ou sofreu algo e de como sua verdade tem o poder de afetar o público, que já não ocupa um lugar meramente voyeurístico, mas é atravessado diretamente pelo testemunho desse corpo que se torna um corpo social e se movimenta através de outrem. Seja numa posição de discordância ou identificação, algo está 
sendo mobilizado por essa relação: "A verdade de um corpo nos afeta, ainda que resista a ser compreendida" (Cornago, 2009, p. 100). Presenciar um corpo que confessa é defrontar-se com o presente e o passado, com alguém que esteve ali e agora está aqui, testemunhando o que viveu. A urgência de narrar histórias diz respeito à memória tanto individual quanto coletiva pois, geralmente por tratar de questões sociais, trazem consigo a necessidade de compartilhamento, de afirmação, de serem contadas em voz alta: "Narramos também para não esquecer. Para não deixar que esqueçam" (Leite, 2014, p. 22). E apesar da aura de real que se estabelece com essa relação de proximidade entre performer e público, o caráter cênico, é evidente, pode estar presente.

A ideia de partilhar memórias e dores se aproxima às noções de liminaridade e communitas, termos do antropólogo britânico Victor Turner que a pesquisadora cubana Ileana Diéguez Caballero (2016) retomou, ao se debruçar sobre manifestações estético-políticas que emergem de acontecimentos sociais. A autora fala de "cenários liminares", que podem estar no campo teatral e artístico, mas não necessariamente. Sobretudo são territórios que abrangem as "práticas e gestos que expõem, na esfera pública, desejos coletivos e possibilitam a construção de outras formas de politicidade" (Caballero, 2016).

Ao transladar as concepções turnerianas ao âmbito das práticas cênicas e sócio-estéticas, insisto em um uso e uma percepção do liminar como zona complexa onde se cruzam a vida e o gesto artístico, a condição ética e a criação estética, a ação da presença em um meio de práticas representacionais. Interessa-me insistir na liminaridade como antiestrutura que põe em crise os status e hierarquias, associada a situações intersticiais, ou de marginalidade, sempre nas bordas sociais e nunca fazendo comunidade com as hierarquias; daí a necessidade de remarcar o caráter político do que entendo como práticas liminares (Caballero, 2016, p. 55).

A partir das situações transitórias, de liminaridade, emerge a communitas, também entendida como uma anti-estrutura que permite o estabelecimento de relações não-hierárquicas entre indivíduos que comungam de memórias, dores, desejos e, nesse encontro efêmero, podem ocorrer experiências transformadoras e subversivas, bem como curativas. 
O que percebo como liminaridade acontece quando em uma realidade emerge outra realidade; quando em uma situação se instala aquilo que está reprimido, cancelado, silenciado. É sem dúvidas uma espécie de retorno, de reaparição. Um ato de memória. (Caballero, 2016, p. 58).

A experiência liminar possibilita o trânsito entre vida e prática artística, pensada por Ileana Diéguez Caballero como um campo expandido em que se cruzam ética e estética, arte e ativismo. A communitas surge na direção contrária da jurisdição, propondo um espaço igualitário construído através da vontade coletiva, do que pode vir a ser e está inscrito na esfera política. É uma experiência que pode suscitar uma dimensão pedagógica, transformadora, possivelmente curativa, subversiva e que também está ligada a um caráter testemunhal, em que a experiência individual se encontra com a coletiva.

Tal aspecto remete ao nome do espetáculo discutido aqui, Panaceia, que significa "pretenso remédio universal para todos os males físicos e morais" ou "tudo aquilo que se considerava válido para resolver qualquer problema"11. A escolha do nome veio de um longo processo não só de criação, mas também de nossos processos subjetivos, como mulheres e como artistas. Especialmente se tratando da última cena, em que houve a possibilidade de uma partilha mais direta com outras mulheres e pessoas transmasculinas, a aliança sugerida pelo termo communitas e em razão de uma condição liminar, foi instaurada ao passo que nossas histórias se tornaram de outras e as histórias de outras se tornaram nossas, por meio de um mútuo reconhecimento. Compartilhamos dores e afetos semelhantes, em um espaço de troca que se constituiu no momento do acontecimento cênico, quando a prática teatral/performativa se tornou também uma prática política, ao romper um silêncio imposto cotidianamente.

À urgência da cena contemporânea de se trabalhar com o real e usar a própria biografia como material para criação dramatúrgica, Cornago chamou de "palcos saturados de confissões e testemunhos" (2009, p. 101), colocados como dispositivo de enunciação. O autor também relacionou esse sintoma ao dispositivo da sexualidade, conceito elaborado por Michel Foucault (1999) e mecanismo do poder

11 "Panaceia", in Dicionário Priberam da Língua Portuguesa, 2008. 
pensado para controle do sexo e das subjetividades através da confissão. A confissão, neste contexto, surge como ciência sexual, ou seja, uma espécie de saber criado por meio de um procedimento que buscava extrair a verdade sobre o sexo: produzindo, assim, discursos sobre ele, como, por exemplo, a sexualidade. A manifestação da verdade e a obediência tornaram-se, então, essenciais para o exercício do poder.

Os dispositivos, entendidos como operadores materiais do poder, se estabelecem por diferentes modos: discursos, instituições, leis, regulamentações, arranjos arquitetônicos. Esse sistema é o que sustenta as relações de poder, que dizem respeito à condução de condutas - o poder de algumas pessoas sobre as outras - bem como às formas de coerção, incitação e indução. Entretanto, para que as relações de poder se concretizem, é necessário que a liberdade individual seja garantida, já que se trata de relações móveis, dispostas estrategicamente em todos os lugares. Assim, o poder dispõe de mobilidade, de modo que formas de resistência podem surgir no interior de suas relações, bem como formas de resistência podem criar novas estratégias de poder, retroalimentando-as.

Pensando estratégias de resistência, Michel Foucault, como já apontado anteriormente, buscou na Antiguidade um modo de vida baseado no cuidado de si: a estética da existência, uma ética que emerge da mobilidade das relações de poder e sugere a subversão delas por meio de um trabalho do indivíduo sobre si mesmo. Dentro da própria estrutura do poder são encontradas brechas a partir das quais o indivíduo busca se reinventar, criar e construir outras formas de existência e identidade, a fim de se desviar dos processos de subjetivação do poder, apropriando-se deles.

O discurso é uma das ambiguidades do poder, que tanto pode ser mecanismo de controle quanto estratégia de oposição. Um exemplo disso é o estupro. Há uma produção de discurso a respeito do estupro que é disseminado e circula pelos grandes veículos de comunicação, pela ciência, pelo sistema jurídico, pelas religiões e, dessa forma, é institucionalizado. Esse discurso institucionalizado legitima sua verdade, e essa verdade determina a forma como a violência será tratada juridicamente, como serão suas representações midiáticas, como vai se 
dar a sua produção de conhecimento científico e, consequentemente, todas as reverberações do tema na sociedade. Ou seja, o modo como formamos uma opinião a respeito do tema vem dessa construção sistemática. Daí a importância de se criar contra-narrativas a partir dos espaços onde estamos ou podemos nos inserir, possibilitando a subversão dos discursos vigentes. Estratégias de resistência são necessárias para impedir que as relações de poder se tornem estados de dominação, em que não há mais formas de luta possíveis.

Óscar Cornago, ao mencionar criações artísticas que partem de uma verdade pessoal, propõe um diálogo entre a prática enunciativa da cena e a estética da existência. Cornago identifica a poética do corpo-testemunha como uma forma de resistência e possibilidade de criação de uma identidade através da ação cênica. Trata-se de resistência ao poder político por meio da criação dramatúrgica, baseada no trabalho sobre si, de artistas que buscam utilizar sua capacidade inventiva para intervir na esfera pública, transcendendo as práticas de (re)existência para além de sua vida privada. É uma possível reinvenção da própria existência e, talvez, da existência coletiva, por meio de um processo imersivo que parte de si e pretende expandir seus efeitos social e culturalmente, buscando formas emancipatórias e políticas para o fazer artístico.

A aura de denúncia que se instaura, cada vez mais, nos trabalhos de artistas e performers contemporâneas impulsiona reflexões, discussões e impressões que, possivelmente, estiveram adormecidas e que, quando instigadas, têm potencial transformador da percepção do cotidiano e do próprio modo de vida. Diante de um discurso que é dispositivo de poder e que pretende reforçar uma narrativa que promove a sensação de impotência, através de uma espécie de melancolização as representações da vítima que reafirmam um lugar de passividade, sugerindo a impossibilidade de recuperação - propor uma contra-narrativa é a possibilidade de movimentar a outra a partir de si mesma, da própria história, do próprio testemunho que se fazem presentes na esfera pública por meio do teatro e da performance, revelando um potencial de transformação individual e coletiva.

Com as experiências de criações artísticas possibilitadas pela performance e pelo teatro, que impulsionaram também uma pesquisa teórico-prática, pude 
suscitar o desencadeamento de reflexões sobre o estupro, fosse durante o processo de investigação, no momento presente da cena - em que nos propusemos a falar abertamente sobre o assunto - ou nas discussões posteriores, tanto quando ouvimos os relatos sobre o espetáculo quanto no desenvolvimento deste artigo. Essa violência - que atravessa a vida de tantas pessoas de forma invasiva, abrupta e angustiante, gerando traumas/feridas que podem acompanhálas por toda a vida - não se encerra no ato, pelo contrário, tem continuidade no pacto social de silêncio, o que tem potencial de fazer com que a sobrevivente se sinta isolada, numa experiência de culpa e repulsa, quando, de fato, compartilha esses mesmos sentimentos com tantas outras mulheres e homens trans que estão ao seu redor, na maioria das vezes sem o saber.

Ao partir da minha própria experiência com o estupro para a criação artística, eu não pretendia causar uma comoção ou algo assim, muito menos propor algum tipo de terapia. Mas entendi, cada vez mais, no decorrer das experimentações e suas trocas, da potência da identificação e do reconhecimento, a importância de propor narrativas diferentes das que tive acesso até então. Narrativas que podem se dar de diferentes formas, partindo da pesquisa autobiográfica, e que podem evidenciar o problema social que é o estupro e o seu modo de operar enquanto dispositivo de uma relação de poder e manutenção do status quo: através do silêncio e da omissão.

De forma consciente ou não, a passagem de um trabalho para o outro aponta um processo de ressignificação da minha experiência. A passagem do silêncio e de um corpo extremamente fragilizado para a capacidade de verbalização, de denúncia. As duas abordagens que tratei aqui surgiram dos mesmos incômodos e seguiram por caminhos diferentes: a primeira expôs os danos psicológicos e físicos que perduram após o estupro, neste caso, através de uma espécie de autoviolência, enquanto a segunda se encarregou de transformar em palavras - ainda que frágeis e trêmulas - todo o ódio contido e não dosado que estava imerso em silêncio. Mas ambas traziam consigo o descontentamento com as representações do estupro e, sobretudo, das sobreviventes, tal como fazem parte do senso comum. Como dito anteriormente, algo foi mobilizado a partir desses trabalhos, 
talvez a percepção do quão comum é o estupro, talvez o espanto de ouvir a palavra que deve ser evitada, de se reconhecer na outra, de se defrontar com o silêncio. Além da denúncia, a possibilidade de transformar a experiência de um estupro em um trabalho artístico, de trazê-lo a público, talvez tenha sido, por si só, uma demonstração de que é possível a subversão de dores. Especialmente dessas dores que compartilhamos, pois são dores decorrentes de problemas sociais. E talvez a forma de transformá-las em potência de cura seja, justamente, produzindo, coletivamente, uma narrativa nossa sobre elas.

\section{Referências}

BERNSTEIN, Ana. A performance solo e o sujeito autobiográfico. Sala Preta, São Paulo, v.1 p. 91-103, 2001.

Disponível em: https://www.revistas.usp.br/salapreta/article/view/57010.

Acesso em: 22 nov. 2020.

CABALLERO, Ileana Diéguez. Liminaridades: práticas de emergência e memória. 0 Percevejo, Rio de Janeiro, v. 8, n. 2. p. 50-59, 2016. Disponível em: http://www.seer.unirio.br/index.php/opercevejoonline/article/view/6496. Acesso em: 8 jan. 2021.

CORNAGO, Óscar. Atuar "de verdade" - a confissão como estratégia cênica. Urdimento, Florianópolis, v. 2, n. 13, p. 99-111, 2009.

DAVIS, Ângela. Mulheres, Raça e Classe. São Paulo: Editora Boitempo, 2016.

DESPENTES, Virginie. Teoria King Kong. São Paulo: n-1 Edições, 2016.

FÉRAL, Josette. Além do limites - Teoria e Prática do Teatro. São Paulo: Editora Perspectiva, 2015.

FERNANDES, Sílvia. Performatividade e gênese da cena. Revista Brasileira de Estudos da Presença, Porto Alegre, v. 3, n. 2, p. 404-419, 2013. Disponível em: https://seer.ufrgs.br/index.php/presenca/article/view/38137. Acesso em: 8 jan. 2021.

Fórum Brasileiro de Segurança Pública. Anuário Brasileiro de Segurança Pública de 2019. Acesso em novembro de 2020. Disponível em: http://www.forumseguranca.org.br/wp-content/uploads/2019/09/Anuario-2019FINAL-v3.pdf. Acesso em: 16 jul. 2020.

FOUCAULT, Michel. "A ética do cuidado de si como prática da liberdade”. In: Ditos \& Escritos V - Ética, Sexualidade, Política. Rio de Janeiro: Forense Universitária, 
2004.

FOUCAULT, Michel. História da sexualidade - volume I: a vontade de saber. Rio de Janeiro: Graal, 1999.

IPEA - Instituto de Pesquisa Econômica Aplicada. Dados do estupro no Brasil. Atlas da Violência. Disponível

em:https://www.ipea.gov.br/atlasviolencia/download/19/atlas-da-violencia-2019. Acesso em: 8 jan. 2021.

IRREVERSÍVEL. Gaspar Noé. França, 2002.

JESUS, Jaqueline Gomes de. Orientações sobre identidade de gênero: conceitos e termos. Brasília, 2012.

LEITE, Janaína. Autoescrituras performativas: do diário à cena. 2014. Dissertação (Mestrado em Artes Cênicas) - Escola de Comunicação e Artes - Universidade de São Paulo. São Paulo, 2014.

LORDE, Audre. Irmã Outsider: ensaios e conferências. São Paulo: Autêntica, 2019.

PAULINA. Santiago Mitre. Argentina: Telefe, 2016.

PERETTA, Éden. As cinco peles: a investigação de si como matriz dramatúrgica no ensino de dança. Congresso da Associação Nacional de Pesquisadores em Dança - ANDA. 2012.

QUILICI, Cassiano Sydow. O ator-performer e as poéticas da transformação de si. São Paulo: Annablume, 2015.

SOUZA, Flávia Bello C. Consequências emocionais de um episódio de estupro na vida de mulheres adultas. Dissertação (Mestrado em Psicologia Clínica). Pontífica Universidade Católica de São Paulo. São Paulo, 2013.

Recebido em: 08/01/2021

Aprovado em: 19/04/2021 